\title{
THE RORIDULACEAE
}

\author{
Nigel Hewitt-Cooper • The Homestead • Glastonbury Road • West Pennard • Somerset, BA6 8NN \\ -UK・sales@hccarnivorousplants.co.uk
}

Keywords: Cultivation, Roridula gorgonias, Roridula dentata, Pameridea.

The family Roridulaceae comprises of a single genus, Roridula, which is represented by two species: $R$. gorgonias and $R$. dentata (see Back Cover). Both are endemic to the Cape region of South Africa, with $R$. gorgonias having its narrow range in the coastal mountains of the South West Cape, and $R$. dentata found in the somewhat more arid area to the north. Both are woody perennial herbaceous shrubs and can attain large proportions with both species capable of reaching $2 \mathrm{~m}$ in height. In habitat both species grow in sandy soils, with $R$. gorgonias enjoying wetter conditions and being often found growing alongside Drosera and Utricularia species.

Much has been written about the symbiotic relationship these plants have with the capsid bugs Pameridea (Fig. 1), and each plant species has its own Pameridea species-P. roridulae on Roridula gorgonias and P. marlothii on Roridula dentata.

Because the plants do not produce their own digestive enzymes, they rely on their incumbent army of hemipteran warriors to consume the vast numbers of animals caught on the resinous leaves. The Pameridea are able to negotiate the sticky forest with the aid of an oil secreted on to their exoskeletons, enabling them to literally run along the leaves and stems unhindered. Once an animal is caught by the plant, the bugs move in, and using needle-like stylets suck the unfortunate victim dry. Insects are the predominant prey item, but as the plants become larger, animals as substantial as birds are also caught. I have had to remove an adult Robin (Erithacus rubecula) from the sticky branches of Roridula dentata which was held fast and had lost many feathers. After feeding, the Pameridea excrete liquid faeces on to the leaves which are then absorbed by the plant. This foliar feed provides the Roridula with the nutrients it requires. It is in effect a complete symbiosis.

The Pameridea species live their complete life cycle on the plant. They can often be seen mating and the females can be observed injecting the eggs in to the bark of the branches during the summer months.

Roridula gorgonias produces long woody stems which branch only after flowering and gradually become multi-headed, each topped with a fairly tight cluster of bronzy green lanceolate leaves $7.5-10 \mathrm{~cm}$ in length (Fig. 2). Each cluster is held erect at first and then slowly fan outwards before dying off and pointing downwards, with the dead growth clinging to the stem so they retain a sticky skirt beneath the green leaves. As the stem lengthens this dead material is shed, exposing the bare brown branches.

Bright pink flowers are produced during the spring and throughout the summer months, each having 5 fine, acutely ovate petals and a cluster of 5 sulphur yellow stamens. These flowers are approximately $2 \mathrm{~cm}$ in diameter, and seem to be attractive to the Pameridea bugs. Indeed, it has been suggested that they aid in the pollination of these plants, although hover flies are also sometimes seen on cultivated plants (Fig. 2). The flowers remain open for several days, finally closing when pollination occurs. Approximately 4 months later, the dark brown 2-3 mm angular seeds are produced (Fig. 4). These have a distinctly verrucose testa, and typically $4-5$ are produced per capsule. When dehiscence occurs, the fruit remains erect (Fig. 5), and as such the seeds can be easily removed by hand with the aid of tweezers. This prompts the question, why are the seeds not readily shed from the mother plant? Could it be that the seeds are retained on the plant until fire burns through the habitat, in much the same way as is seen with some Protea species? 


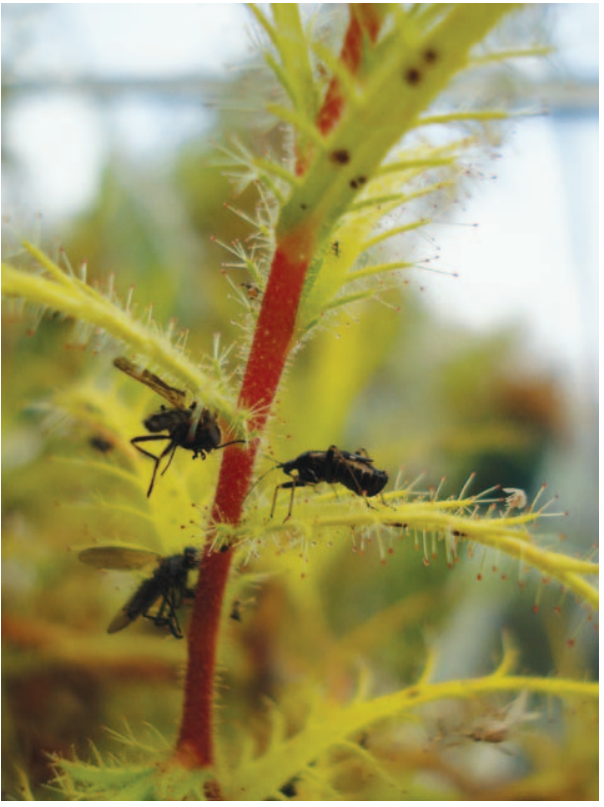

Figure 1: Pameridea on Roridula dentata.

Roridula dentata is a rather more untidy plant (Fig. 3) which branches freely from a young age without the necessity of flowering. The leaves are similar in shape to $R$. gorgonias but are pinnate, having 7-8 dentations on either side and are to 7.5 $\mathrm{cm}$ in length. They are a light apple green color and grow from a bright red soft stem which gradually becomes woody and brown with age (Fig. 3). Unlike $R$. gorgonias the leaves are produced singly along the stem from an open rosette, but age and die back in the same way, remaining attached for some time before falling from the plant. An interesting observation with this species is the pungent smell it emits during hot weather, best described as a mix of sweet corn and sewer gas!

As the plant develops and branches it can become large and rambling, eventually attaining over $2 \mathrm{~m}$ in height, and having an equal width (see Back Cover). Pale pink flowers with 5 broadly ovate, acutely tipped petals to $2 \mathrm{~cm}$ in diameter are produced during the late winter and early spring, and again these seem to attract the attention of the Pameridea who may aid pollination.

Four to five seeds are produced per capsule some 4 months later (Fig. 4). These are pale brown in color, cigar shaped, bear a distinct longitudinal ridge along one plane, and have an alveolate (honeycombed) surface. They are larger in size than $R$. gorgonias at about 4-5 $\mathrm{mm}$ in length and 1.5-2 $\mathrm{mm}$ in width. Dehiscence is achieved by the seed capsule splitting longitudinally along 3 planes, and the seeds fall to the ground as the fruit is pendulous (Fig. 5). Interestingly, very few seeds are to be found caught on the resinous leaves, suggesting that the seeds are either thrown clear of the mother plant (which is doubtful as seeds are usually found at the base), or they have a coating which in some way does not adhere to the leaves.
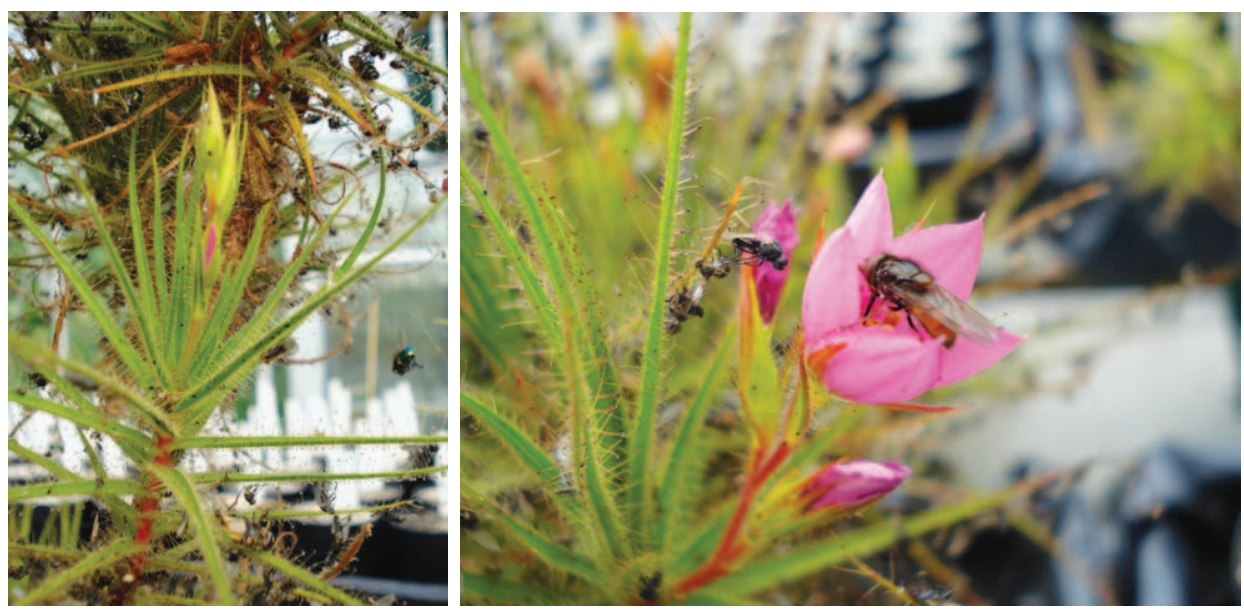

Figure 2: Roridula gorgonias growth point (left) and hover fly on the flower (right). 

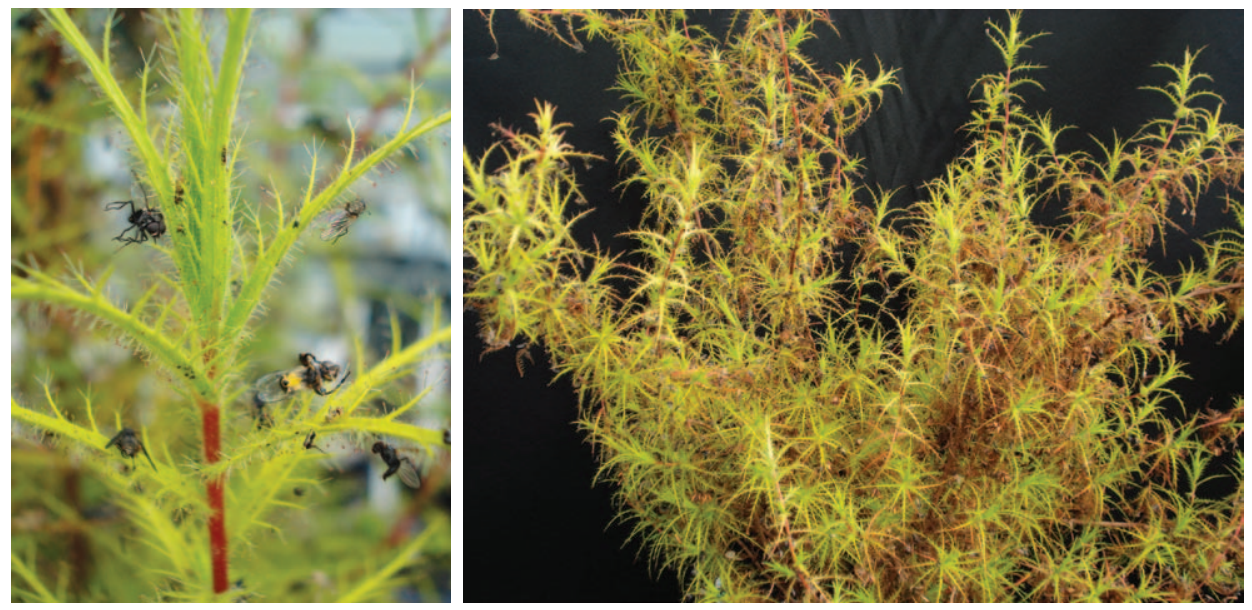

Figure 3: Roridula dentata growth point (left) and plant (right).

There has been little written about the cultivation of the Roridulaceae and they remain fairly rare in collections-certainly this is the case for $R$. dentata which requires rather more care to maintain successfully. The biggest obstacle to overcome is that of seed germination, which must be treated first. Both species require the same method of germination and perhaps the biggest clue lies with the fact that $R$. gorgonias retains its seeds as mentioned above. As has been published previously, many South African species require fire to germinate, or rather the smoke and chemicals contained therein. The easiest method of smoking seeds uses the method described by Lowrie (1996) and Reiner (2003), using a barbeque to smolder dry peat. This will replicate the effects of a bush fire and encourage growth.

Once treated keep the seeds in a sunny position, ideally in a greenhouse and keep wet. Germination can take several weeks, and eventually the testa will split and a root will emerge. The seedling will grow and shed the testa allowing the leaves to develop. $R$. dentata often takes a further few weeks to shed its' seed coat and it can appear to be struggling to dispose of it. Don't be tempted to remove it as you are likely to snap the developing shoot inside and kill the plant. In August 2007, I

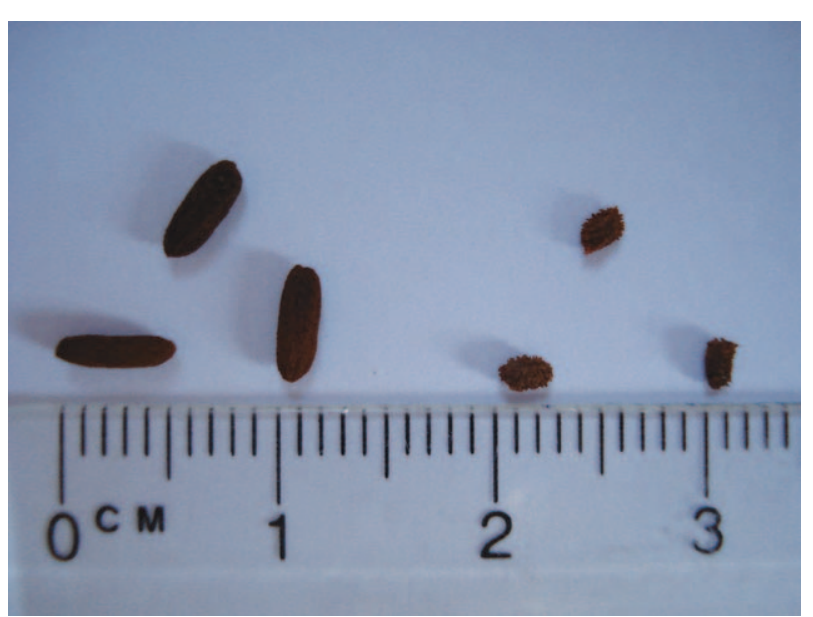

Figure 4: Seed comparison: Roridula dentata (left) and $R$. gorgonias (right). tried this method of smoking the seeds with 7 seeds of each species, and within 6 weeks all of the $R$. gorgonias had produced upright shoots, and all of the $R$. dentata had split and were starting to produce their first root. Hardly a scientific experiment due to the low number of seeds sown, but interesting just the same.

Seedlings of $R$. gorgonias develop more slowly than $R$. dentata, which is faster in all respects, but because of the difficulty of this species it remains far rarer. 

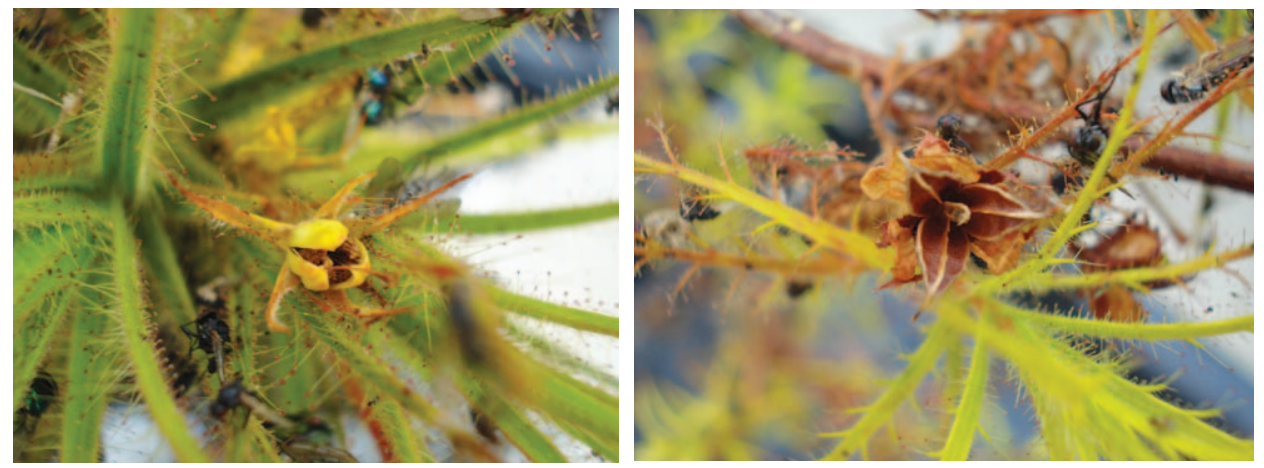

Figure 5: Roridula gorgonias dehiscence (left) and Roridula dentata dehiscence (right).

Cultivation

Roridula gorgonias is the easier of the species; we'll look at the successful cultivation of this plant first.

Light: Keep in full sun. I suspect that low light levels will produce etiolated, sickly plants which would not survive for long.

Water: Stand in $1 \mathrm{~cm}$ of rain water during the spring/summer months, and just damp in winter. Do not allow them to dry completely as they will rapidly decline. I lost a $60 \mathrm{~cm}$ specimen by allowing this to happen. When it was re-watered it gradually rotted and died over a period of several weeks-a sad end to a plant I had nurtured for 6 years.

Compost: I grow mine in a mix of peat moss and silver sand in a ratio of 1:2. This allows for free drainage during the winter so the plant does not remain too wet. The addition of 1 part coarse perlite will also aid in this, but bear in mind they will need careful and regular scrutiny to avoid drying too much. A good sized container allows healthy root run, and for a plant $30-60 \mathrm{~cm}$ high a 5-liter $25-\mathrm{cm}$ pot is ideal.

Temperature: During the summer months the temperature in the greenhouse can rise to over $38^{\circ} \mathrm{C}$ with no negative effects. A winter minimum of $7^{\circ} \mathrm{C}$ is adequate. Growth ceases over the winter months and the population of Pameridea crashes, due probably to a combination of low temperature and lack of food. A few banded crickets (Gryllodes sigillatus), of the variety sold as reptile food, placed on the leaves will provide sustenance, but beware not to position too many as they are likely to rot during the cooler, damper months. However, the population will return in the spring when the temperature increases and the eggs laid the previous year will hatch.

General: As long as the conditions above are maintained this is a fairly easy and rewarding plant to grow. Allow good space around the plants as the branches tend to rot if they are cramped together and are touching. Good air movement is also an important factor to consider, especially during the winter months when greenhouse doors and windows are closed. A circulation fan is recommended to discourage fungal spores in the air from settling on any dead material and causing molds to flourish.

Roridula dentata requires similar conditions, but with some extra care-especially during the winter.

Light: As for R. gorgonias, it requires full sun to grow well.

Water: Stand in $1 / 2 \mathrm{~cm}$ of rain water during the spring and summer months when in full growth, allowing the tray to dry before replenishing. During the winter, the compost must be just damp, allowing a little water at a time to the base to ensure the plant does not desiccate. Conversely, too much water will rot the plant in a matter of days. 
Compost: This species prefers dryer conditions than $R$. gorgonias and therefore likes a mix of peat, silver sand, and perlite in a ratio of 1:2:1. A large container is advisable to allow good root run, and will also prevent the compost drying too quickly. I have a $120 \mathrm{~cm}$ plant in a 25-liter pot. A 5-liter $25-\mathrm{cm}$ pot will suffice for smaller individuals.

Temperature: As for $R$. gorgonias.

General: Most failures of this species occur during the winter months when they are extremely susceptible to rotting. Even in ideal conditions large plants will lose individual growth points to rot. They simply turn a grey/green color and wither. Regular inspection is required as rot can spread rapidly and affect whole branches, so be sure to remove any affected growth immediately, cutting back to healthy growth to allow a good margin. Even during the summer months this can occur during damp and overcast periods so vigilance is necessary all year. Good air movement is essential and air circulation fans I feel are imperative during the winter.

As mentioned above too much water will cause the plants to rot. I lost a $150 \mathrm{~cm}$ specimen when a small leak developed in the greenhouse roof. The gradual dripping fell directly on to the soil surface and saturated the pot. Within only a few days the whole plant had rotted.

Cuttings seem possible with this species. They must be fresh red stems, as the older woody stems never appear to root. Nevertheless, it is a slow process and roots seem to take a number of months to develop. Keep the cuttings small, ideally $7.5-10 \mathrm{~cm}$, and push them in to a peat and sand mix to a depth of approximately $2.5 \mathrm{~cm}$. Stand them in $2 \mathrm{~cm}$ of water until they have resumed growth, which will possibly be before roots develop, and keep in full sun. Once they are clearly growing, gradually reduce the amount of water to encourage the roots to form.

Because of the precise conditions $R$. dentata requires, I would only recommend it to the experienced grower who has succeeded well with $R$. gorgonias, and who has the correct growing facilities. However, to succeed with these incredible plants is ample reward for the effort required as they are surely among the most unusual subjects of the plant kingdom.

\section{References}

Lowrie, A. 1996. An easy method to smoke treat carnivorous plant seed. Bull. Austral. Carniv. Plant Soc. 15(2): 3-5.

Obermeyer, A. 1970. Droseraceae. In: L. Codd, B. De Winter, J. Killick, and H. Rycroft (eds.) Flora of Southern Africa, Vol. 13, Government Printer, Pretoria: 187-201.

Reiner, M. 2003. Die Gattung Roridula und ihre Freunde. 13 p. http://www.drosophyllum.com/ Dateien/Roridula.pdf

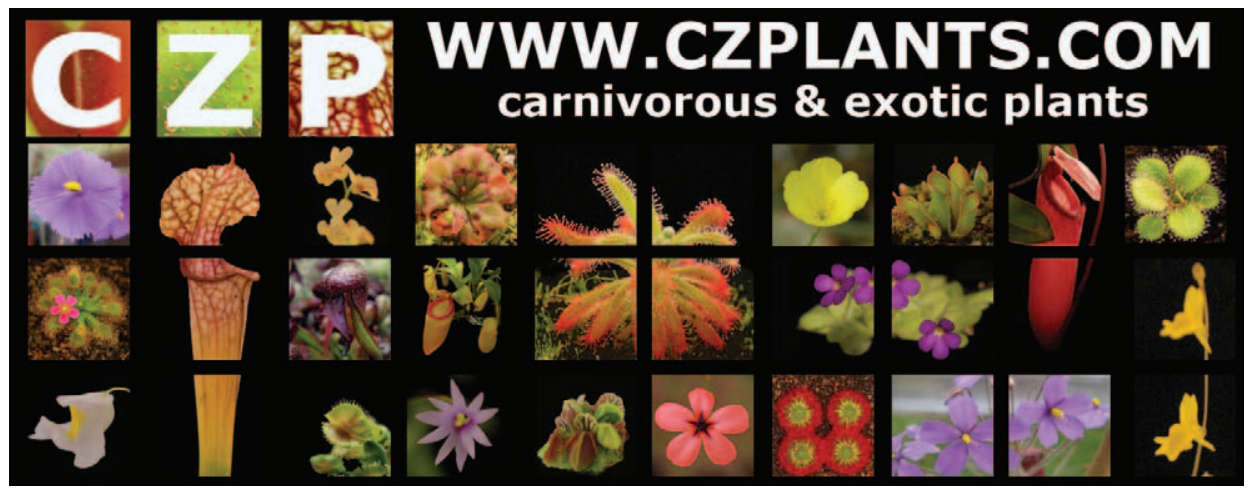




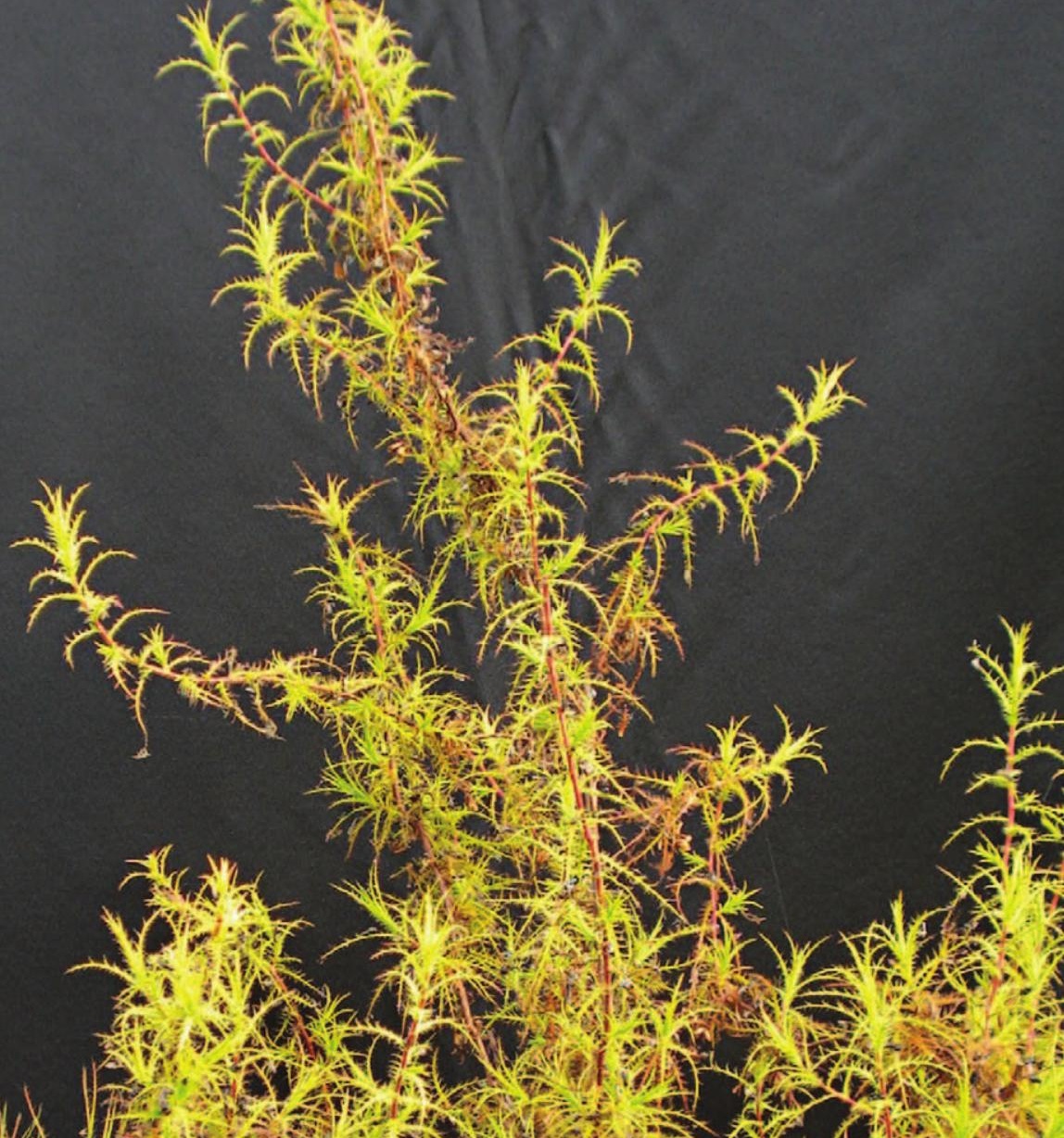
H.t. 62

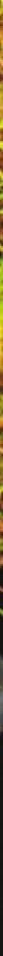




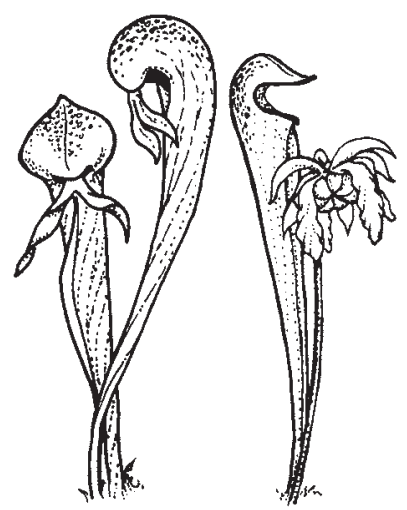

\section{CARNIVOROUS \\ PLANT \\ NEWSLETTER}

Journal of the International

Carnivorous Plant Society

www.carnivorousplants.org

Volume 41, Number 4 December 2012

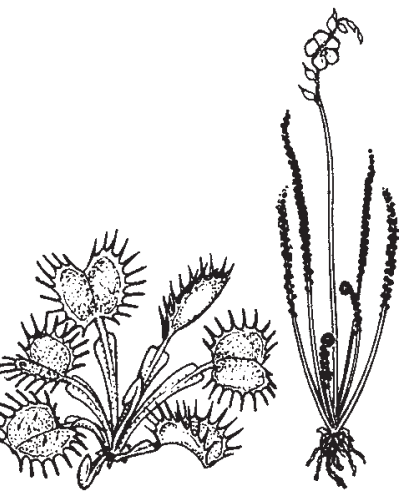

Front Cover: Unfurling Drosophyllum Iusitanicum leaf spiral. Photo by Barry Rice. Article on page 143.

Back Cover: A comparison of Roridula gorgonias (left) and Roridula dentata (right). Photo by Nigel Hewitt-Cooper. Article on page 146.

Carnivorous Plant Newsletter is dedicated to spreading knowledge and news related to carnivorous plants. Reader contributions are essential for this mission to be successful. Do not hesitate to contact the editors with information about your plants, conservation projects, field trips, or noteworthy events. Advertisers should contact the editors. Views expressed in this publication are those of the authors, not the editorial staff.

All correspondence regarding dues, address changes and missing issues should be sent to the Membership Coordinator at the ICPS. Do not send such correspondence to the editors. Checks for subscriptions should be made to the ICPS in US funds. Dues for 2013 are \$35 for the first year of membership; renewals are \$30 per year.

ICPS, Inc.

2530 Patra Drive

Richmond, CA 94803, USA

icps@carnivorousplants.org

President Michael Baldwin, michael@carnivorousplants.org

Vice President_Marcel van den Broek, marcel@carnivorousplants.org

Secretary

Treasurer

Cindy Slezak, cindy@carnivorousplants.org

Board Member

Richard Myers, richard@carnivorousplants.org

Board Member

Bob Ziemer, bob@carnivorousplants.org

Board Member

Jan Schlauer,jan@carnivorousplants.org

Seed Bank Manager

Brian Barnes, Conservation Director, brian@carnivorousplants.org

John Brittnacher, john@carnivorousplants.org (see seed bank ad in this issue)

Editors:

Managing Editor_Bob Ziemer, bob@carnivorousplants.org

Science Editor

Science Editor

Editor

Jan Schlauer,jan@carnivorousplants.org

Fernando Rivadavia, fernando@carnivorousplants.org

Barry Rice, barry@carnivorousplants.org

Date of effective publication of the September 2012 issue of Carnivorous Plant Newsletter: 31 August 2012.

The ICPS is the International Cultivar Registration Authority (ICRA) for the names of cultivated carnivorous plants according to the International Code of Nomenclature for Cultivated Plants. Send relevant correspondence to the ICPS, Inc.

Carnivorous Plant Newsletter is published quarterly in March, June, September, and December by the ICPS, Inc., 2530 Patra Drive, Richmond, CA 94803, USA. Periodicals postage paid at Richmond, CA and additional mailing offices. Postmaster: Send address changes to ICPS, Inc., PMB 322, 1564-A Fitzgerald Drive, Pinole, CA 94564-2229, USA. Printed by Allen Press, Inc., 810 E. 10th Street, Lawrence, KS 66044. Logo and masthead art: Paul Milauskas. (C) 2012 Carnivorous Plant Newsletter. All rights reserved. ISSN \#0190-9215 